\title{
De Deus à Diferença \\ trajetória das matrizes filosóficas na educação brasileira
}

Cristiane Maria Marinho

professora da Universidade Estadual do Ceará

\section{RESUMO}

O presente artigo tem o objetivo de enfatizar as diversas matrizes filosóficas que influenciaram a educação no Brasil, tanto nos seus aspectos práticos, quanto nos seus aspectos teóricos, tendo em vista que muitos dos estudos que fazem a confluência entre Filosofia e Educação não explicitam a importância dessas grandes matrizes filosóficas que nortearam os rumos da educação brasileira. O fluxo do artigo segue a trajetória histórica da Colônia até os atuais dias republicanos, perseguindo os conceitos filosóficos mais determinantes em cada uma dessas matrizes filosóficas, de Deus à Diferença, e mapeando seus principais desdobramentos.

Palavras-chave: Filosofia; Educação; Brasil.

\section{RESUMEN}

El presente artículo tiene por objeto enfatizar las diversas matrices filosóficas que influenciaron la educación en el Brasil, tanto en sus aspectos prácticos como en sus aspectos teóricos, considerando que muchos de los estudios que hacen la confluencia entre Filosofía y Educación no explicitan la importancia de estas grandes matrices filosóficas que nortearon las rutas de la educación brasileña. El flujo del artículo sigue la trayectoria histórica de la Colonia hasta los actuales días republicanos, persiguiendo los conceptos filosóficos más determinantes en cada una de estas matrices filosóficas, de Dios hacia la Diferencia, y identificando sus principales desdoblamientos.

Palabras-clave: Filosofía; Educación; Brasil.

Filosofia e Educação - ISSN 1984-9605 - v. 4, no 1, abril-setembro de 2012 


\section{Introdução}

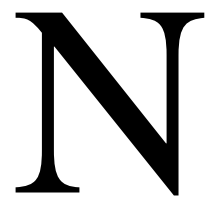

o Brasil, a educação, ao longo de sua trajetória histórica, foi influenciada pelas diversas matrizes filosóficas europeias e norte-americanas, tanto no seu direcionamento prático quanto na sua produção teórica. Mesmo assim, nem sempre essas matrizes mereceram o devido destaque em estudos da área educacional, na qual quase sempre prevalecem aspectos educacionais, ideias pedagógicas ou políticas educacionais.

Assim sendo, no presente artigo serão elencadas e realçadas as matrizes filosóficas que foram mais expressivas no nosso país, bem como as práticas e as teorias educativas resultantes delas, com o objetivo de melhor observar e compreender as matrizes filosóficas contemporâneas e suas inserções na atualidade educacional brasileira.

\section{Colônia (1500-1822): de Deus à ciência mitigada}

No Brasil, na época colonial, merece destaque a atuação pedagógica dos jesuítas, iniciada em 1549, com a chegada de um grupo de jesuítas, liderados pelo padre Manoel da Nóbrega, e vai até o final do século XVI. A atuação jesuítica, na qual predomina a catequese, prossegue do século XVII até o ano de 1759, século XVIII, com a sua expulsão pelo Marquês de Pombal.

Na segunda etapa da ação jesuítica, houve a expansão do sistema de ensino e a mudança de plano pedagógico. Segundo Ghiraldelli (2006, p. 25), "A pedagogia aplicada nesses colégios evoluiu do plano de Nóbrega para a adoção do sistema do Ratio Studiorum", que trazia o pensamento aristotélico-tomista como matriz filosófica norteadora da prática educacional, determinando o código pedagógico jesuítico, submetendo a filosofia à teologia, para a qual serve de auxiliar. Nas diversas regras do Ratio Studiorum é possível perceber que sua matriz filosófica aristotélica-

Filosofia e Educação - ISSN 1984-9605 - v. 4, no 1, abril-setembro de 2012 
tomista impunha e valorizava uma filosofia retórica, apoiada em disputas lógicas formais a partir da obra aristotélica e nas disputas medievais tomistas. Por isso, a realidade terrena ficava preterida em função dos estudos sobre os anjos, os sacramentos e a encarnação, em busca do conhecimento e amor do criador. Era uma filosofia voltada para o ensino da doutrina cristã e exercida sob uma forte estrutura hierárquica com vistas à salvação das almas da danação do inferno.

Dessa forma, Correr (2006) realça que no século XVI, na busca de formar o homem para Deus, a visão de Aristóteles tornava-se o instrumento de formação intelectual plena para a teologia cristã, pois representava a máxima autoridade filosófica. A essa perspectiva somava-se o pensamento de Santo Tomás, que sobre a teoria aristotélica, "desenvolve a teoria da ordem natural, em que a natureza humana, com suas próprias forças, é capaz de fortalecer-se, disciplinar-se e 'produzir' boas obras" (Correr, 2006, p. 52). Aos jesuítas coube alcançar esse objetivo através da educação que levava à fé cristã.

Em uma segunda fase do período colonial (1759 e 1807), o Marquês de Pombal promove reformas que expulsam os jesuítas de Portugal e do Brasil. Essas reformas visavam adequar os interesses de Portugal e de suas colônias à modernidade europeia e substituir as ideias religiosas e metafísicas dos jesuítas pelas ideias racionalistas e científicas do Iluminismo, com predominância dos ideais liberais, seculares e democráticos (Ghiraldelli, 2009).

As ideias de influência iluminista chegavam a Portugal através de portugueses residentes no exterior, chamados de "estrangeirados". Dentre esses, ressaltamos o nome de Luís Antônio Verney (1713-1792), personagem importante na reforma da educação, para quem o processo educacional precisava se libertar do monopólio jesuítico, cujo ensino se

Filosofia e Educação - ISSN 1984-9605 - v. 4, no 1, abril-setembro de 2012 
mantinha preso a Aristóteles e resistia aos métodos modernos da Ciência (Saviani, 2007).

Com a expulsão dos jesuítas do Brasil, seus colégios foram substituídos pelas aulas régias, inspiradas pelo viés iluminista quanto ao método de estudar, pois o método de estudo jesuítico foi considerado obscuro e distanciado da prática. Inversamente, o novo método sugerido por Verney era baseado no ensino prático e em coisas úteis. A diretriz filosófica presente nas reformas pombalinas da instrução pública era iluminista, empirista e de crítica à Escolástica e baseada no livro epistolar Verdadeiro método de estudar, de Verney.

Tanto o livro de Verney quanto as reformas pombalinas sofreram a influência da filosofia empirista e iluminista lockeana, formulada a partir do combate à doutrina das ideias inatas e metafísicas. Para o pensador português, as reflexões presentes nos dois livros de Locke, Ensaio acerca do entendimento humano e Alguns pensamentos sobre a educação, eram complementares. Para ambos os pensadores, a realidade cultural daquela época exigia uma transformação radical dos estudos e o critério era o da utilidade da cultura (Verney, 1952).

Outro resultado das Reformas Pombalinas foi a Reforma da Universidade de 1772, em Portugal, que teve forte influência empirista com os compêndios do filósofo italiano Antônio Genovesi (1713-1769), Instituições de Lógica de 1773 (Paim, 1986). Assim, surge uma nova corrente oficial denominada de empirismo mitigado, na qual não interessava a precisão conceitual, mas "a simples exaltação do conhecimento experimental e à condenação frontal da metafísica tradicionalmente cultivada em Portugal" (Paim, 1986, p. 26).

Paim (2008) se refere ao empirismo mitigado como via de superação do aristotelismo escolástico português e o caracteriza, a partir do texto de Genovesi, como uma crítica ao aristotelismo dominante. Crítica esta que

Filosofia e Educação - ISSN 1984-9605 - v. 4, no 1, abril-setembro de 2012 
procurava incorporar certas premissas do empirismo lockeano à tradição racionalista. Tratava-se de um empirismo mitigado, atenuado, por não minimizar o papel da razão e não levar às últimas consequências as políticas liberais que acompanhavam o empirismo.

Também no Brasil, com a expulsão da Companhia de Jesus, houve a implantação das aulas régias, que funcionavam conjuntamente com seminários e colégios das ordens religiosas. Nesse contexto, destaca-se o Seminário de Olinda, que seguia os moldes iluministas dos Estatutos da Universidade de Coimbra. Nele estudavam leigos, religiosos e candidatos aos estudos superiores em Portugal. Por isso, era representativo na formação intelectual de várias gerações.

O Seminário de Olinda, que orientava seu ensino pelas ideias das reformas pombalinas presentes, especialmente, em $O$ verdadeiro método de estudar, de Verney, foi fundado em 1800, pelo bispo da Igreja Católica Azeredo Coutinho, formado pela Universidade de Coimbra. Contrapunhase, portanto, às ideias religiosas e, baseado nas ideias laicas inspiradas no Iluminismo, defendia o direcionamento do Estado na educação. Seus estatutos buscavam ensinar não uma ciência universal, mas princípios elementares, adequados aos padres e aos leigos para uma formação de cidadãos indagadores da Natureza (Saviani, 2007).

Para Azeredo Coutinho, o padre deveria se formar simultaneamente em sacerdote e filósofo da natureza e, por isso, acrescentou aos estudos eclesiásticos os estudos das ciências naturais nos estatutos do Seminário. Para ele, o filósofo naturalista deveria deixar de ser somente um homem de gabinete, tornar-se um homem prático, para complementar e enriquecer o conhecimento limitado do homem silvestre e ignorante, pois: "seria preciso que o habitante das brenhas e dos sertões fosse filósofo ou que o filósofo habitasse as brenhas e os sertões" (Coutinho apud Saviani, 2007, p. 112).

Filosofia e Educação - ISSN 1984-9605 - v. 4, no 1, abril-setembro de 2012 
Contudo, politicamente, o resultado obtido na formação dos seus alunos foi contraditório. Apesar de visar ao fortalecimento do reino português unificado sob a bandeira de um déspota esclarecido, o Seminário de Olinda também formou republicanos e se tornou um centro que abrigou a liderança da revolução pernambucana de 1817, na luta por um Brasil independente e republicano (Saviani, 2007).

A última fase colonial do Brasil, o período joanino, é marcado pela vinda da família real, em 1808. Saviani (2007, p. 113) afirma que "nessa nova fase as ideias pedagógicas oriundas do pombalismo continuaram inspirando as iniciativas de Dom João, ainda que sua motivação principal tenha sido de caráter administrativo", pois havia a necessidade de formar quadros para administrar e defender militarmente o reino, que transferiu sua sede para o Rio de Janeiro. Para tanto, foram organizados cursos nos moldes das aulas régias, eminentemente técnicos: aulas de cirurgia e de anatomia; cursos de serralheiros, de agricultura; laboratório de química, geologia e mineralogia; etc. Azevedo (1958) afirma que, apesar de todos os seus limites, a fase joanina representa um marco de superação completa e radical do programa escolástico e literário do período colonial, mesmo que impelido tão somente pelo cuidado de utilidade prática e imediata.

Contudo, o entusiasmo prático inspirado pela vertente filosófica empirista não teve equivalência nas teorias filosóficas que rondavam a intelectualidade da época. Contraditoriamente, a matriz filosófica que teve mais expressão nesse período buscava questionar os limites e obstáculos do empirismo mitigado. Pode-se até afirmar que é um momento de transição do empirismo mitigado para o ecletismo espiritualista.

Silvestre Pinheiro Ferreira, português, professor de filosofia na Universidade de Coimbra e diplomata, foi um dos representantes mais importantes desse período. Depois de ter exercido várias funções pela

Filosofia e Educação - ISSN 1984-9605 - v. 4, no 1, abril-setembro de 2012 
Europa, em 1810 vem para o Brasil, na condição de professor de filosofia, e publica suas aulas com o título de Preleções Filosóficas.

Silvestre Pinheiro tentou resgatar a filosofia da prisão do conhecimento positivo da natureza, efetuado por Verney, que, ao tentar se contrapor ao verbalismo escolástico da cultura portuguesa, acaba por fechar a filosofia num âmbito cientificista, no qual a moral e a política ficavam à margem. Para Silvestre, Verney teria radicalizado a importância do conhecimento prático e científico e sufocado, dessa maneira, o mérito das coisas do espírito.

Paim (1984, p. 254) defende que esse estudioso foi o primeiro pensador "a atacar frontalmente o empirismo mitigado, despreocupado da defesa da filosofia tradicional, em nome da própria coerência do empirismo". À filosofia restrita do empirismo e confundida com ciência, contrapunha a ideia de filosofia como sistema. Em virtude disto e do magistério de filosofia que exerceu no Rio de Janeiro, lançou as bases para o debate dos temas modernos, discutidos pela intelectualidade de então, inspirando a consciência filosófica e política brasileira da época no seu traço conservador e liberal. Por muito tempo, seu livro foi o único texto em filosofia disponível para os estudiosos. Em virtude de suas críticas ao empirismo mitigado, Silvestre Pinheiro é considerado responsável pela transição ao ecletismo espiritualista, corrente filosófica que vai predominar no Império brasileiro.

\section{Império (1822-1889): entre o ecletismo e o cientificismo}

Em 1823, após a Proclamação da Independência, D. Pedro I convocou a Assembleia Nacional Constituinte para reformar a estrutura administrativa do país e, ao constatar a necessidade de uma legislação sobre instrução pública, instituiu um concurso. O vencedor de tal concurso se inspirou literalmente na obra Cinco memórias sobre instrução pública, um livro de

Filosofia e Educação - ISSN 1984-9605 - v. 4, no 1, abril-setembro de 2012 
1791, de autoria de Condorcet, filósofo iluminista que defendia uma relação liberal entre Estado e escola (Saviani, 2007) e reconhecia a instrução como necessária para o exercício da liberdade política.

Contudo, tanto a proposta de Martim Francisco, quanto o projeto de elaboração de uma política de instrução pública para o Brasil foram postos de lado. A Assembleia Constituinte e Legislativa foi dissolvida e, em 1824, o imperador outorgou a primeira Constituição do Império do Brasil, na qual constava apenas que a instrução primária era gratuita para todos os cidadãos.

A discussão sobre o a instrução pública foi retomada em 1826, na reabertura do Parlamento. O projeto mais votado era também respaldado nas ideias iluministas de Condorcet. Mas, da mesma forma que o anterior, esse projeto também não vingou, prevalecendo o projeto "Escolas de Primeiras Letras", de 1827, que possibilitava tão somente o acesso aos saberes básicos. Contudo, essa lei também não obteve êxito, inviabilizando novamente um sistema nacional de instrução pública (Saviani, 2007).

Em 1834, uma reforma repassou para as províncias a responsabilidade sobre o ensino elementar e secundário, atribuindo à Coroa a função de promover o ensino superior. A educação da elite ficou a cargo do poder central, e a do povo confiada às províncias. Contudo, no ensino secundário houve uma exceção, em 1837 foi fundado no Rio de Janeiro o Colégio D. Pedro II, funcionando sob a jurisdição da Coroa, para educar a elite intelectual e servir de padrão de ensino para os demais liceus do país, sendo o único a realizar os exames que conferia o grau de bacharel que dava acesso aos cursos superiores (Aranha, 2006).

Pode-se inferir que o descaso com a educação elementar da população brasileira, fruto de uma política elitista, foi uma das razões que impediram a absorção das ideias liberais e iluministas de Condorcet por duas vezes seguidas. A noção iluminista de escola pressupunha a distribuição das Luzes

Filosofia e Educação - ISSN 1984-9605 - v. 4, no 1, abril-setembro de 2012 
por todos os habitantes, mas só o colégio que formava a elite do país foi de fato beneficiado com elas (Saviani, 2007).

Esse período se caracterizou pelas posições liberais aceitas conforme as conveniências do poder imperial e pela realização das ideias iluministas somente para os ricos. Daí, a aceitação predominante da matriz filosófica do Ecletismo Espiritualista nos círculos intelectuais da elite política e educacional, pois sua capacidade de reunir elementos diferenciados viabilizava a conciliação necessária aos interesses do império. As reflexões filosóficas de Silvestre Pinheiro Ferreira, associadas à prática docente e política, prepararam o terreno para a corrente filosófica do Ecletismo Espiritualista, cuja base inspiradora foi a filosofia de Victor Cousin, que, influenciada por Hegel, buscava uma mediação entre o empirismo e o idealismo (Paim, 1984).

O Ecletismo Espiritualista foi a primeira corrente filosófica estruturada no Brasil, nas décadas de 1830 e 1840. Foi unanimidade entre os intelectuais no período de 1830 a 1880, sendo adotado como filosofia oficial no Colégio Pedro II e, por isso, tornou-se obrigatório nas demais instituições de ensino secundário e nos cursos anexos de faculdades, com a adesão de professores e intelectuais. Foi dominante de 1850 até 1870, quando começou a ser contestado pela Escola do Recife.

Esta corrente filosófica se divide em três períodos: Ciclo de formação (de 1833 a 1848) - caracterizado por um animado debate filosófico entre naturalistas e espiritualistas, no qual a questão central era preservar a liberdade e incorporar o liberalismo político num sistema empirista coerente; Ciclo de apogeu (de 1850 a 1880) - adotado como filosofia oficial, obrigatória no colégio Pedro II e nos liceus estaduais. A sua posição foi de prestígio inconteste no seio da intelectualidade e da elite política. Nas discussões filosóficas, o tema do conhecimento perde posição para a busca

Filosofia e Educação - ISSN 1984-9605 - v. 4, no 1, abril-setembro de 2012 
dos fundamentos da moral; Ciclo de declínio (a partir de 1870) - substituído lentamente pelo Positivismo (Paim, 1986).

O Colégio Pedro II praticava uma educação elitista, que correspondia à estrutura social de então, marcada fortemente pelas diferenças econômicas e pelos grandes atrasos liberais. Assim, oferecia um ensino de cunho universalista, literário e enciclopédico, com alguma concessão aos estudos científicos, para formar bacharéis em humanidades, cujo diploma dispensava os exames para ingresso nas Academias. Assim, os estadistas do Império, inspirados no bacharelismo e na cultura europeia criaram um instituto de ensino secundário aristocrático, afastado das questões práticas e da ciência, um instrumento de seleção social (Azevedo 1958).

O programa de filosofia estabelecido pelos ecléticos do Pedro II influenciou o conteúdo do programa de filosofia em nível nacional, pois era obrigatório em todos os exames gerais de preparatórios ao ensino superior e exigia o conhecimento da própria doutrina eclética (Paim, 1999).

Em 1880, houve concurso para provimento da Cadeira de Filosofia do Colégio Pedro II, com a aprovação de Silvio Romero (1851-1914), "interrompendo a tradição de preenchê-la com partidários do ecletismo espiritualista" (Paim, 1999, p. 30). Contudo, isso não significou uma mudança automática de orientação, pois há indícios de que o ecletismo do Pedro II e nos Liceus Estaduais tenha prevalecido até a República.

$\mathrm{O}$ ano de 1870 inicia o período final do Ecletismo Espiritualista e seu declínio, com o surgimento da Escola de Recife, até sua posterior e total superação no início da República. Ocorre também a emergência das correntes cientificistas e a ascensão do Positivismo. Porém, os espiritualistas ecléticos, representantes da filosofia oficial do Segundo Império, não se curvaram diante dessas novas ideias, chegando mesmo a combatê-las (Paim, 1986).

Filosofia e Educação - ISSN 1984-9605 - v. 4, no 1, abril-setembro de 2012 
A Escola do Recife, partindo de obras de Comte, Darwin, Taine, Renan e outros para compor uma espécie de 'frente' cientificista, combateu a monarquia, tida como obstáculo ao progresso. É nesse movimento que surge o positivismo como corrente filosófica expressiva no Brasil. Entretanto, a Escola do Recife, foi multifacetada e, apesar de sua significativa reflexão na área filosófica, fez incursões em diversas áreas do conhecimento, mas foi a filosofia que constituiu o elemento unificador desse movimento encabeçado por Tobias Barreto (Paim, 1986).

A produção filosófica do grupo teve início em 1875, quando Sílvio Romero escreve o texto, até hoje desaparecido, Deve a Metafísica ser considerada Morta? O texto foi fruto de sua participação num Concurso da Faculdade de Direito, no qual defendeu a morte da Metafísica pelo Positivismo.

Tobias Barreto, Silvio Romero e outros, estabeleceram os alicerces de criação do grupo da Escola de Recife. Sua obra, tal qual a própria Escola, não obedeceu somente a uma única orientação filosófica. Ao contrário, mudou de referencial teórico ao longo de sua trajetória intelectual (Positivismo, Spencerianismo, neokantismo, etc.) até se fixar no tema da cultura na última fase da Escola, a cultura como antítese da natureza. Tobias Barreto com o culturalismo filosófico e Sílvio Romero com o culturalismo sociológico (Paim, 1986).

A Escola do Recife revolucionou a Faculdade de Direito do Recife, de onde surgiu, promovendo discussões em torno de disputas filosóficas e jurídicas que iam desde a polêmica entre o ecletismo e o cientificismo, até o questionamento da influência filosófica francesa em prol da filosofia alemã. Sua influência extrapolou as terras pernambucanas, tendo ramificações em todo o Brasil. Em Fortaleza, por exemplo, teve o grupo denominado Academia Francesa do Ceará, fundado em 1872, liderado por Raimundo Antônio da Rocha Lima.

Filosofia e Educação - ISSN 1984-9605 - v. 4, no 1, abril-setembro de 2012 
Primeira República (1889-1930): ciência, crença, prática e liberdade

A organização de um sistema nacional de ensino foi a questão educacional que predominou no final do Império e continuou na Primeira República, bem como a substituição da mão-de-obra escrava pelo trabalho livre e a importância da educação nesse processo. Contudo, nenhuma dessas questões teve desdobramento prático e o sistema nacional de ensino não foi implantado nessa época, resultando o acúmulo de um enorme déficit educacional (Saviani, 2007).

A Primeira República é atravessada em seu pensamento pedagógico pela discussão sobre a importância do Estado no desenvolvimento da sociedade e a impossibilidade da política burguesa em resolver as contradições sociais de base do capitalismo (Saviani, 2007). Nesse contexto político-educacional brasileiro, várias matrizes filosóficas foram marcantes e determinaram certos aspectos institucionais e/ou teóricos da realidade educacional brasileira. Salientemos aqui o Positivismo, o Catolicismo, o Pragmatismo e o Anarquismo.

O positivismo, corrente filosófica criada por August Comte (17981857), foi uma reação ao idealismo teológico e metafísico e apoiava-se no primado da razão científica. Essa corrente filosófica influenciou muitos intelectuais do Brasil republicano, dentre eles Benjamin Constant, que fez a primeira reforma nacional da instrução pública no Brasil, inspirada nos moldes positivistas de uma educação baseada na ciência.

Pode-se considerar três aspectos mais marcantes da influência positivista na educação brasileira: a realização de reformas do ensino primário e secundário, norteadas pela hipótese comteana de que o real se esgota na ciência, à qual também devem ser submetidas a política e a moral; a recusa pela elite política da implantação da Universidade, desnecessária por não produzir saber prático, e a conservação do ensino superior como formação profissional; a adesão ao positivismo do professorado de ciências

Filosofia e Educação - ISSN 1984-9605 - v. 4, no 1, abril-setembro de 2012 
(Escola Politécnica, Colégio Pedro II, etc. no Rio de Janeiro e em diversas outras capitais) (Paim, 1984).

A força do catolicismo, por sua vez, era expressa na hegemonia católica no campo educacional, que não se abalou nem com o ideário iluminista e a expulsão dos jesuítas, nem com o conflito entre a Igreja e o Império. Até mesmo a exclusão republicana do ensino religioso nas escolas públicas e a separação entre o Estado e Igreja fortaleceram uma reação espiritualista.

O sergipano Jackson de Figueiredo organizou, no Brasil, o movimento católico leigo para divulgar a doutrina católica através do Centro Dom Vital e da Revista A Ordem, criados por ele em 1922, com os quais se inicia a fase cultural do movimento católico no Brasil. Tanto Jackson quanto as instituições ligadas a ele sofreram a marca indelével da filosofia de Santo Agostinho via Pascal, para quem Deus, diante da razão, é o Bem, do contrário seria injusta a condenação eterna se não houvesse a certeza do Deus que oferece salvação, que se realiza com o amor a Deus, aos homens e a submissão à autoridade instituída por Deus, Jesus Cristo e sua Igreja (Fontes, 1998).

Figueiredo foi mentor intelectual de Alceu Amoroso Lima, importante líder católico do Brasil no século XX e um dos fundadores do Instituto Católico de Estudos Superiores (1932) e da Universidade Católica do Rio de Janeiro (1941). Contudo, nessa nova fase do catolicismo, a influência de Agostinho é substituída pela de Jacques Maritain, com um tomismo modernizado, a "influência de Maritain e de revistas como Esprit, La Vie Intelectuelle, Revue Thomiste foi enorme" (Paim, 1984, p. 424). O maritainismo criava no sistema tomista um lugar para a ciência moderna, para a intervenção política e para a valorização da cultura mais apropriada para os novos tempos (Paim, 1986).

Filosofia e Educação - ISSN 1984-9605 - v. 4, no 1, abril-setembro de 2012 
Assim, a influência do pensamento católico na educação na Primeira República tomou uma forma de resistência ativa, através de atitudes práticas como publicação de livros, artigos em revistas e jornais, livros didáticos e formação de professores nas suas próprias Escolas Normais. Em 1928, os católicos organizaram, também, nas diversas unidades da federação, Associações de Professores Católicos (APCs) que, posteriormente, comporiam a Confederação Católica Brasileira de Educação (Saviani, 2007).

A primeira Constituição republicana, de 1891, explicitava que o governo central não era responsável pela instrução pública e delegava aos Estados a função de oferecer a instrução primária. Por isso, em 1892, São Paulo inicia as reformas estaduais, mas concentrando esforços somente na escola primária e inovando com a criação dos grupos escolares substituindo as escolas isoladas.

Na década de 1920, a reforma paulista inaugurou um importante ciclo de reformas estaduais e deu início à influência filosófica pragmatista, que orientou todo o ideário escolanovista no final desta década. Os fatos que expressam essa influência pragmatista foram: publicação, em 1929, do livro de Lourenço Filho, intitulado Introdução ao estudo da Escola Nova; fundação da ABE (Associação Brasileira de Educação) em 1924; primeira Conferência Nacional de Educação 1927; três principais reformas estaduais com Lourenço Filho (1922), Anísio Teixeira (1925) e Fernando Azevedo (1928).

O início do século XX se caracterizou pelo debate das ideias liberais, entre a concepção tradicional do liberalismo, na filosofia de Herbart, e a concepção humanista moderna do liberalismo, na filosofia de Dewey. O resultado das mudanças sociais da República (fim da escravidão, trabalho assalariado, industrialização etc.) foi o avanço do pensamento do filósofo americano sobre as ideias do filósofo alemão (Ghiraldelli 2009). Assim foi

Filosofia e Educação - ISSN 1984-9605 - v. 4, no 1, abril-setembro de 2012 
que, na metade da década de 1920, os brasileiros leram Dewey (1859-1952) e conheceram melhor sua proposta pedagógica da escola nova.

As diferenças teóricas entre os dois filósofos repercutiam em suas posições relativas à educação. Herbart esperava formar "pessoas capazes de dominar e reproduzir um determinado saber - um saber intelectual e principalmente moral" (Ghiraldelli, 2002, p. 25). Em Dewey, ao contrário, "a educação era a organização de experiências de crescimento em benefício da possibilidade de mais ricas experiências, aumentando a diversidade e a capacidade de inventividade humana" (Ghiraldelli, 2002, p. 19).

Outra alternativa de enfrentamento teórico para os problemas surgidos na Primeira República foi o Anarquismo vindo com os imigrantes. A liberdade é o princípio básico do Anarquismo, base para a estrutura da teoria anarquista, sua concepção de homem, de mundo e de sociedade. É por esse princípio, a ser construído socialmente, que o Anarquismo se denomina Socialismo Libertário ou Libertarismo e constata que historicamente o homem nunca foi livre, mas sim escravizado pelo seu principal senhor, o Estado, a ser destruído (Gallo, 1990).

$\mathrm{O}$ anarquismo não pode ser visto como uma doutrina ou como um sistema filosófico fechado, pois ele é uma atitude que nega a autoridade e afirma a liberdade (Gallo, 1990). Existem três princípios teóricos básicos que caracterizam o movimento anarquista: autonomia individual, autogestão social e internacionalismo; e três princípios práticos: a ação direta, as associações operárias e a greve geral (Gallo, 1990).

No Brasil, com a propagação do ideário anarquista, as associações de classe criaram as primeiras escolas para os operários e seus filhos: Escola Libertária Germinal - 1903; Escola Livre, em Campinas - 1908; Escolas Modernas, que apareceram em 1910, inspiradas na proposta de escola racionalista de Ferrer i Guàrdia. Posteriormente, essas Escolas se 
transformaram em associações, ligas, sindicatos e centros culturais (Passetti e Augusto, 2008).

Para a educação libertária, além da escola, eram importantes os jornais anarquistas da época, pois a educação era um amplo processo. Assim, a alfabetização deveria ser uma prática que deveria ir da escola à universidade, e não somente o domínio elementar da escrita e da leitura “oferecido em nome da devoção à desobediência, à integração econômica, à ascensão social e à adesão política no processo de moldagem da criança para a vida conformista" (Passetti e Augusto, 2008, p. 56).

Com os anos de 1920 veio o declínio das ideias libertárias na condução do movimento operário, que finda seguindo as orientações comunistas, consequência da experiência soviética, que, no Brasil, determina a fundação do Partido Comunista Brasileiro (PCB), em 1922, com a participação dos anarcossindicalistas (Saviani, 2007).

\section{Segunda República (1930-1937): missão francesa e pragmatismo versus neotomismo}

Na Segunda República, as matrizes filosóficas que marcaram as teorias e as instituições educacionais foram, praticamente, as mesmas do primeiro período republicano. Porém, o Positivismo teve um papel menos relevante e o marxismo ganhou um vulto maior no panorama filosófico brasileiro. Três matrizes filosóficas influenciaram mais fortemente os seguintes acontecimentos da educação brasileira: o Manifesto dos Pioneiros da Educação Nova, com influência do pragmatismo; a fundação da USP, marcada pela filosofia francesa, determinando os rumos do estudo de Filosofia no Brasil; o surgimento das Pontifícias Católicas, representativas da marca do pensamento católico sustentado na tradição aristotélico-tomista.

O conflito filosófico entre aristotélico-tomistas e pragmatistas, representados por católicos e escolanovistas, na Associação Brasileira de

Filosofia e Educação - ISSN 1984-9605 - v. 4, no 1, abril-setembro de 2012 
Educação (ABE), motivou o Manifesto dos Pioneiros da Educação Nova, publicado em 1932, como resultado da IV Conferência Nacional de Educação. Tudo isso trouxe como consequência a retirada dos educadores católicos da $\mathrm{ABE}$ e a fundação da Confederação Católica Brasileira de Educação em 1933 (Saviani, 2007).

Contudo, a diretriz teórica presente no Manifesto não foi somente o pragmatismo de Dewey. Estava presente, também, a sociologia de Durkheim, bem como uma pluralidade de áreas ligadas à educação (Ghiraldelli, 2009). A multiplicidade de diversas correntes filosóficas, próprias aos integrantes do movimento escolanovista, certamente marcou as influências filosóficas díspares que incidiram sobre o Manifesto (Saviani, 2007).

Estudiosos apontam a fundação da USP - Universidade de São Paulo -, em 1934, como consequência dos conflitos entre os tenentes ligados à ditadura getulista e a elite intelectual paulista, que, derrotada, viu a necessidade da criação de uma universidade, em São Paulo, para a formação de quadros dirigentes no Estado e no País. Nesse processo, foi decisiva a missão francesa que veio com a fundação da USP, promovendo a renovação e modernização dos estudos das ciências humanas no país. A palavra “missão” traduziria certa atividade messiânica (Marinho, 2009a).

Antes da fundação do departamento de filosofia da USP, a filosofia brasileira, predominantemente tomista ou eclética e de caráter amador, impossibilitava uma leitura científica e rigorosa dos textos clássicos. A missão francesa uspiana de filosofia possibilitou sistematicidade metodológica e abertura temática aos estudos filosóficos, impôs um limite ao amadorismo e à mera erudição com o acesso aos clássicos na década de 30, e pela adesão ao método estrutural na década de 60, com a leitura exegética das grandes obras.

Filosofia e Educação - ISSN 1984-9605 - v. 4, no 1, abril-setembro de 2012 
No primeiro período destacaram-se Roger Bastide e Claude LéviStrauss no ensino das Ciências Sociais e Jean Mangüé na Filosofia. O professor Mangüé predominou nessa primeira etapa, a qual teve características mais culturais do que científicas, inovando o ensino de filosofia com a abordagem desta a partir de filmes, romances, teatro, livros de filosofia em suas línguas originais e conversações com os alunos; abolindo o estudo de filosofia pelos manuais ou traduções; instituindo os cursos monográficos como diretriz imprescindível nos estudos filosóficos. Por tudo isso, Mangüé, a USP e a filosofia francesa tiveram um papel decisivo na nossa formação filosófica.

Depois do conflito com os escolanovistas, em 1932, a preocupação e a necessidade da Igreja em formar líderes intelectuais nos moldes do espírito católico levaram à fundação da Associação dos Universitários Católicos, semente do Instituto Católico de Estudos Superiores, também em 1932, que, por sua vez, daria surgimento às Faculdades Católicas e às Pontifícias Universidades Católicas. A primeira PUC a ser criada foi a do Rio de Janeiro, em 1947. Depois vieram: PUC-SP, em 1947; PUC-RS, em 1948; PUC Campinas, em 1955; PUC-MG, em 1958; dentre outras (Saviani, 2007).

A bandeira da luta dos católicos contra os renovadores escolanovistas consistia, principalmente, no combate à laicização do ensino. Para a Igreja, religião e pedagogia são inseparáveis, haveria um "naturalismo pedagógico" que estabelecia a hierarquia Família, Igreja e Estado como responsáveis pela educação. Esse argumento teria um "caráter filosófico-teológico, tendo, pois, sentido universal, fundamentado na filosofia perene sistematizada, a partir de Aristóteles, por Santo Tomás de Aquino" (Saviani, 2007, p. 258).

Os neotomistas brasileiros tiveram um peso decisivo na organização do ensino superior particular, principalmente a partir dos anos 1930, apesar de terem começado desde 1908, quando os beneditinos fundaram a 
Faculdade de Filosofia São Bento, embrião da Universidade Católica de São Paulo, centro de cultivo e de irradiação da filosofia neotomista, com influência da Universidade de Louvaina. Leonardo Van Acker e Leonel Franca foram grandes expoentes do neotomismo no Brasil (Ghiraldelli, 2009).

Contudo, apesar do combate da Igreja ao escolanovismo, em determinada altura ficaram claras as "virtudes do ideário da escola nova que, afinal, ganhava adeptos velozmente na vanguarda do professorado" (Ghiraldelli, 2009, p. 42). O resultado foi um escolanovismo católico neotomista, hierarquizado, baseado no princípio de autoridade, privilegiando a ordem sobre o progresso e considerando que o povo deveria ser "conduzido por uma elite responsável, formada segundo princípios da 'reta moral cristã'” (Saviani, 2007, p. 259). Essa elite seria formada nas PUCs, criadas com essa finalidade.

\section{Quarta República (1945-1964): liberalismo e socialismo cristão}

A segunda metade do século XX foi marcada pela polêmica entre a escola pública e a escola particular, desencadeada pela Conferência "A escola pública, universal e gratuita”, proferida por Anísio Teixeira, em 1956. Os católicos, vendo seus interesses contrariados, deturparam o teor do discurso com a acusação de comunismo, aproximando o pragmatismo do marxismo. A ABE saiu em defesa de Anísio, a Igreja contra atacou reiterando as acusações. De um lado, os defensores da escola particular: Igreja e proprietários de escolas privadas; de outro lado, defensores da escola pública: três grupos de intelectuais com formações filosóficas diferenciadas (Saviani, 2007).

O primeiro grupo era liberal-pragmatista, inspirado na filosofia de Dewey e filiado ao movimento da Educação Nova. Dentre eles, estavam Anísio Teixeira, Fernando Azevedo e Lourenço Filho. Para esse grupo, o

Filosofia e Educação - ISSN 1984-9605 - v. 4, no 1, abril-setembro de 2012 
homem não é um valor absoluto, pois é um ser de necessidades práticas, as quais devem também nortear a educação (Saviani, 2007).

O segundo grupo, liberal-idealista e kantiano, era representado pelo jornal $O$ Estado de S. Paulo e por professores da área de filosofia e história da educação da USP, como Roque Spencer Maciel de Barros e Laerte Ramos de Carvalho. Para esse grupo, o homem se torna racional, livre e moral pela educação, que transforma a animalidade em humanidade (Saviani, 2007).

O terceiro grupo, liderado por Florestan Fernandes, era socialista e se diferenciava tanto do liberalismo-idealista kantiano, para o qual a educação independia das condições sociais, quanto do liberalismo-pragmatista deweyano, para o qual a educação ajustava à realidade social. Diversamente, a visão socialista compreendia a educação a partir da sociedade e a considerava um fator de transformação (Saviani, 2007).

No final da década de 1950 e início dos anos 1960, devido à industrialização, à aglomeração urbana, ao direito de voto condicionado à alfabetização etc., aumenta a mobilização popular em torno da cultura e da educação. Nesse período, para boa parte da Igreja, a educação não era mais sinônimo de catequese, mas de conscientização e politização do povo, ou seja, de educação popular que não mais significava somente o desenvolvimento da instrução pública em um sistema nacional, universalização da educação elementar e erradicação do analfabetismo.

O pensamento de Paulo Freire surge, nesse cenário, como proposta educacional de libertação do homem oprimido através de um processo de conscientização, seguido de uma práxis libertadora: transformação da consciência ingênua em consciência crítica; comunicação dialógica; respeito e igualdade entre educando e educador. Esse procedimento é libertador e transformador e constitui uma pedagogia como prática de liberdade.

Filosofia e Educação - ISSN 1984-9605 - v. 4, no 1, abril-setembro de 2012 
Para vários estudiosos (Saviani, 2007; Severino, 1997; Paiva, 1980), há uma grande diversidade de correntes filosóficas no pensamento freiriano, mas prevalece o existencialismo cristão. Para Severino (1997), essa questão é complexa e polêmica devido a sua formação, ao caráter prático de sua proposta pedagógica e a multiplicidade de influências que sofreu, mas predomina o humanismo existencialista cristão de Jaspers e Marcel.

Contudo, houve mudança de referencial filosófico ao longo de sua reflexão. As referências do livro Educação como prática da liberdade remetem ao existencialismo cristão personalista (Jaspers, Alceu Amoroso Lima, Gabriel Marcel, Maritain, etc.) (Saviani, 2007) e as referências de Pedagogia do Oprimido se aproximam da dialética e do marxismo (Marx, Engels, Hegel, etc.) ausentes nas obras anteriores, mas sem significar adesão ao marxismo (Saviani, 2007).

\section{Regime militar (1964-1985):} metodologismo, tecnicismo, reprodutivismo-crítico e anarquismo

Um acontecimento importante no período militar foi a missão francesa filosófica uspiana da década de 60, que atuou de forma expressiva na vida cultural do país: discussões sobre o militarismo; presença do intelectual na vida pública; formação de quadros para estudo, pesquisa e divulgação da Filosofia no Brasil. Contudo, a influência mais marcante dessa missão no estudo da filosofia no Brasil foi o método estrutural.

Os grandes expoentes do método estrutural foram Guéroult, Goldschmidt e Granger que trouxeram novas convicções sobre o estudo da Filosofia, que deveria ser o estudo da História da Filosofia, através do método estrutural, ou seja, explicitação rigorosa da estrutura dos textos filosóficos. Até então predominava o amadorismo e o impressionismo no estudo e no ensino da Filosofia, bem como a utilização dos comentadores ao invés dos textos originais.

Filosofia e Educação - ISSN 1984-9605 - v. 4, no 1, abril-setembro de 2012 
A obra de referência da metodologia estruturalista, trazida para a USP pelos franceses da década de 60, é o texto Tempo lógico e tempo histórico na interpretação dos sistemas filosóficos, de Victor Goldschmidt, que busca aproximar a filosofia e sua história, elaborando uma historiografia filosófica. Essa metodologia se tornou dominante na época por elevar o estudo da Filosofia à objetividade das ciências "e em torno da qual gravitaria o ensino da filosofia entre nós" (Arantes, 2000, p. 17).

A predominância do método estrutural no ensino da Filosofia no Brasil suscitou diversas críticas: foi mais uma influência estrangeira em nosso filosofar; inibiu criatividade, autonomia de pensamento, objetos de reflexão, material filosófico; constituiu mera mudança de senhor filosófico, mas permaneceu a subserviência de repetir os grandes filósofos vindos de fora etc. Essa subserviência se mostraria na precária produção acadêmica filosófica com seus temas repetidos.

O Instituto de Pesquisas e Estudos Sociais (IPES) foi fundado em novembro de 1961, por empresários ligados à Escola Superior de Guerra (ESG) e ao Instituto Brasileiro de Ação democrática (IBAD), com o objetivo de combater, em diversas áreas, a mobilização popular e suas organizações culturais e esteve atuante durante quase dez anos do Regime Militar. A sua atuação mais decisiva foi no âmbito da educação com a proposta pedagógica Tecnicista. A proposta militar de uma política educacional economicista e o ensino como qualificação profissional culminou no acordo MEC-USAID, estabelecido entre empresários brasileiros e norte americanos, via IPES (Saviani, 2007).

A teoria econômico-filosófica norteadora desses acontecimentos a favor de uma educação tecnicista era a Teoria do Capital Humano, de Theodore Schultz, um liberalismo que se pautava pelos princípios de racionalidade e eficiência com um mínimo de dispêndio e o máximo de produtividade. Os livros de Schultz que traziam essas ideias eram $O$ valor

Filosofia e Educação - ISSN 1984-9605 - v. 4, no 1, abril-setembro de 2012 
econômico da educação (1963) e O capital humano: investimento em educação e pesquisa (1971), que logo foram traduzidos no Brasil. A educação tecnicista no capital humano é pautada pelos ideais de racionalidade, organização, objetividade, eficiência e produtividade e "o professor é um técnico que, assessorado por outros técnicos e intermediado por recursos técnicos, transmite um conhecimento técnico e objetivo" (Aranha, 2006).

A pós-graduação brasileira, criada na década de 1970, foi inspirada nos parâmetros da pedagogia tecnicista e do modelo norte americano, com o objetivo de formação de quadros que viabilizassem as metas econômicas e científicas do governo militar. Contudo, a pós-graduação brasileira formou um pensamento mais crítico que operativo, a partir da tendência críticoreprodutivista, denominada assim por Saviani, influenciada pela filosofia e sociologia marxistas francesas. Ela era crítica porque compreendia a educação a partir das condições sociais, e reprodutivista porque concluía que a educação reproduzia as condições sociais vigentes (Saviani, 2007).

As teorias crítico-reprodutivistas são: teoria do sistema de ensino enquanto violência simbólica, da obra $A$ reprodução: elementos para uma teoria do sistema de ensino, de Pierre Bourdieu e Jean-Claude Passeron; teoria da escola enquanto aparelho ideológico de Estado, presente no texto Ideologia e aparelhos ideológicos de Estado, do filósofo marxista francês Louis Althusser; teoria da escola dualista, do livro L'école capitaliste em France, de Baudelot e Establet.

Essas teorias inspiraram muitos intelectuais da época que trabalhavam com a educação brasileira. A partir delas foram feitas denúncias de como o militarismo manobrava a educação para impor ideias e reproduzir a estrutura social capitalista (Ghiraldelli, 2009).

Nas décadas de 1970-80 ressurge o interesse pela pedagogia libertária, com a intenção de criticar e se contrapor à escola formal existente, protestar

Filosofia e Educação - ISSN 1984-9605 - v. 4, no 1, abril-setembro de 2012 
contra o autoritarismo do regime militar, bem como se opor à educação tecnicista. Assim é que o não-diretivismo de A. S. Neill e o seu livro Liberdade sem medo tiveram uma boa aceitação na comunidade educacional brasileira desse período. A obra relatava a experiência autogestionária da escola-comunidade inglesa Summerhill. Para a escola interessavam mais as relações interpessoais e menos a problemática da aprendizagem das matérias. Nesse sentido, para Neill, a educação deveria ter um só objetivo: a cura da infelicidade (Ghiraldelli, 2009).

Outro indicador da retomada das ideias libertárias no Brasil foi a publicação, em 1978, do texto Francisco Ferrer e a pedagogia libertária de Maurício Tragtenberg, reeditado em 1982 como parte do seu livro Sobre educação, Política e sindicalismo (Gallo, 2007). Dentre outras questões, o pensamento de Tragtenberg dinamizou críticas à burocratização da escola; promoveu o fortalecimento do marxismo heterodoxo; inseriu a discussão sobre a pedagogia libertária no meio acadêmico; e revitalizou o universo das discussões em torno da liberdade humana, base primordial do anarquismo. Bem como trouxe à luz uma discussão subjacente aos princípios anarquistas (Ghiraldelli, 2009, Gallo, 2007).

\section{0-2010: capital, razão instrumental, redescrição e Diferença}

O final dos anos 1970 foi marcado por vários fatores que irão consolidar o longo processo de redemocratização do Brasil, que teve início com a Abertura, em 1985. Foi nesse quadro, marcado por contradições políticas, que o pensamento marxista no Brasil, no campo da educação, ganhou efervescência e o nome de Saviani mostrou-se expressivo (Ghiraldelli, 2009). Para Saviani, as pedagogias liberais, que ele chamava de não-críticas, e as teorias denominadas por ele de crítico-reprodutivistas estavam distantes de uma educação democrática, sendo necessário recorrer à categoria de luta de classes, pois a luta de classes existia também na escola. Inicialmente

Filosofia e Educação - ISSN 1984-9605 - v. 4, no 1, abril-setembro de 2012 
Saviani chamou essa nova proposta, encabeçada por ele, de pedagogia revolucionária, que depois passou a ser denominada pedagogia históricocrítica.

A fundamentação teórica da pedagogia histórico-crítica é explicitamente o pensamento de Marx, para quem "as condições históricas de produção da existência humana [...] resultaram na forma da sociedade atual dominada pelo capital" (Saviani, 2007, p. 420). Sua proposta é a elaboração de uma concepção pedagógica em consonância com a concepção de mundo e de homem inerente ao materialismo histórico.

No período de 1960-70, enfraqueceu o debate propriamente filosófico no campo educacional, predominando uma discussão mais psicologizada e pedagogizada, que segue nos anos de 1980, juntamente com uma reflexão marxista. Os anos de 1990 inauguram novos referenciais filosóficos para a abordagem da educação, apesar de não se tornarem unânimes, pois continuam a vigorar outros referenciais filosóficos (Ghiraldelli, 2009).

Os novos paradigmas filosóficos contemporâneos da educação no Brasil põem em xeque algumas características da modernidade, tais como a sua pretensão universalista e a razão instrumental. A partir desses parâmetros filosóficos, algumas indagações tem mobilizado a pesquisa educacional na atualidade brasileira: a educação pode se guiar pela universalidade e pela fundamentação racional? O sujeito iluminista ainda é o ideal educativo? (Fonte, s/d).

Atualmente, a produção filosófica educacional no Brasil tem se caracterizado por um questionamento dos paradigmas fundados na razão iluminista. Os principais pensadores nos quais essa crítica se apoia são: Foucault, Derrida, Barthes, Lyotard, Baudrillard, Deleuze e Guattari, pensadores denominados pós-modernos, pós-estruturalistas ou pós-críticos. Alguns temas presentes em suas pesquisas filosófico-educacionais são:

Filosofia e Educação - ISSN 1984-9605 - v. 4, no 1, abril-setembro de 2012 
imanência; relação poder-saber; afeto e corpo; singular versus universal; questionamento do sujeito iluminista; Diferença.

Diversos estudiosos (Ghiraldelli, 2009; Severino, 1997; Silva, 2002; Pagni \& Cavalcanti, s/d; Paraíso, 2004) concordam que as vertentes filosóficas mais expressivas que passaram a influenciar o pensamento educacional brasileiro, a partir da década de 1990 do século XX e primeira década do século XXI, foram: a Escola de Frankfurt; os neopragmatistas norte americanos, principalmente Rorty; e os contemporâneos franceses Foucault e Deleuze.

$\mathrm{O}$ questionamento da hegemonia da racionalidade e dos valores da modernidade já estava presente na Teoria Crítica dos pensadores da Escola de Frankfurt com três temas recorrentes: a dialética da razão iluminista e a crítica à ciência; a dupla face da cultura e a discussão da indústria cultural; e a questão do estado e suas formas de legitimação na moderna sociedade de consumo (Ghiraldelli, 2009).

No Brasil, a influência da Teoria Crítica vem desde o final da década de 1960, com a contracultura e Marcuse, para quem a herança iluminista teria se transformado em força de opressão e de alienação. Nos anos de 1970 e 1980, a influência frankfurtiana no Brasil vem de Adorno, Horkheimer e Benjamin com a questão da produção cultural numa sociedade de massas (Severino, 1997).

A partir de 1990, essa influência parte da perspectiva habermasiana, na qual "se impõe superar o 'modelo unilateral de racionalidade, comportando unicamente uma dimensão cognitivo-instrumental"” (Severino, 1997, p. 184). É nesse momento que se encontra uma interface significativa de pesquisa na área de filosofia da educação (Severino, s/d). Dentre outros, pode-se citar os seguintes nomes: Bruno Pucci, Antônio Alvaro Zuin, Newton-Ramos de Oliveira, Nadja Hermann Prestes, Marilu

Filosofia e Educação - ISSN 1984-9605 - v. 4, no 1, abril-setembro de 2012 
Fontoura de Medeiros, José Pedro Boufleuer (Ghiraldelli, 2009; Severino, 1997).

Paulo Ghiraldelli se destaca entre os estudiosos da Filosofia da Educação ao aproximar filosofia e educação. Diante das limitações dos movimentos marxistas na abordagem filosófica da educação e do pedagogismo que predominava nessa área, ele se aproximou do neopragmatismo rortyano (Marinho e Rocha, 2009), no qual fazer filosofia é promover redescrições antifundacionais e antiessencialistas. O homem é pensado sem recorrer a essencialismos e, por isso, o "homem, não tendo essência, é aquilo que ele se dispuser a ser, e [...] sua capacidade de criar linguagens e posturas adequadas a essas linguagens é infinita" (Ghiraldelli, 2001, p. 127). Assim, as pessoas são motivadas a alterar suas crenças e comportamentos a partir de convencimentos racionais. É essa perspectiva que acentua o caráter íntimo da filosofia rortyana com a educação, para quem o homem é infinitamente educável (Ghiraldelli, 2001).

As reflexões de Ghiraldelli no cenário brasileiro são expressivas pela sua grande produção intelectual (livros, blogs, sites, etc.) e por ser um grande divulgador das ideias rortyanas no Brasil. Nessa mesma linha, merece destaque Suzana de Castro com expressiva produção bibliográfica e significativa atividade de divulgação do pensamento neopragmático norte americano.

Já o início da intercessão Foucault/Deleuze e educação no Brasil data de 1993 (Paraíso, 2004), na 16 Reunião Anual da ANPED, com trabalhos de Tomaz Tadeu da Silva e Lucíola Santos. Em 1994, surge também publicação de Sandra Corazza, referência no surgimento dos estudos póscríticos no Brasil. Tomaz Tadeu, entre outras coisas, avalia os limites e um considerável esgotamento da teoria crítica, o que implicaria na necessidade de novos paradigmas filosóficos para a interpretação dos processos educacionais e aponta os princípios da teoria pós-crítica e da filosofia da

Filosofia e Educação - ISSN 1984-9605 - v. 4, no 1, abril-setembro de 2012 
diferença deleuziana como novos referenciais contra-hegemônicos para se pensar a educação.

Alfredo Veiga-Neto, com seus estudos foucaultianos, é outro nome importante no surgimento desses novos referenciais teóricos pós-modernos na educação. Mais dois nomes, agora cearenses, são significativos na recepção, divulgação e produção de ideias deleuzianas ligadas à educação: Daniel Lins e Sylvio Gadelha. Walter Omar Kohan, argentino naturalizado brasileiro, trabalha principalmente nas áreas de filosofia da educação, filosofia para crianças e ensino de filosofia. Seus principais referenciais filosóficos são Deleuze, Foucault e Ranciére. Silvio Gallo é outro filósofo imprescindível nesse universo de teorizações pós-modernas ligadas à educação. Inicialmente enveredou pelas trilhas do anarquismo, depois pesquisou Foucault e atualmente investiga o ideário deleuziano, sempre na perspectiva de relacionar essas filosofias com a educação.

\section{Conclusão}

Esse breve mapeamento da influência filosófica sobre a educação no Brasil é, obviamente, delimitado, portanto, maleável e processual, mas cumpre o objetivo de realçar os contornos, nem sempre reconhecidos, das matrizes filosóficas na educação brasileira a partir de sua multiplicidade, heterogeneidade e força de animação das práticas e teorias educativas.

As matrizes filosóficas da educação brasileira não fizeram um percurso linear e progressivo. Pelo contrário, variaram em seu movimento entre idas e vindas, fortalecimentos e fragilidades, recuperações e perdas definitivas, simultaneidades e solidões. Assim, esse breve histórico não se pretende definitivo e muito menos exaustivo, pois tanto a influência recebida é transformada quanto o seu fluxo é contínuo. A trajetória continua...

Filosofia e Educação - ISSN 1984-9605 - v. 4, no 1, abril-setembro de 2012 


\section{Referências}

ARANHA, Maria Lúcia de Arruda. História da educação e da pedagogia: geral e

Brasil. $3^{a}$ ed. rev. e ampl. São Paulo: Moderna, 2006.

ARANTES, Paulo. In: Conversas com filósofos brasileiros. Marcos nobre e José Marcio Rego (Org.). São Paulo: Ed. 34, 2000. . O departamento francês de ultramar. São Paulo: Paz e Terra, 1994.

AZEVEDO, Fernando de. A transmissão da cultura. In: A cultura brasileira: Introdução ao estudo da cultura no Brasil, tomo terceiro. $3^{a}$ ed. São Paulo: Edições Melhoramentos, 1958.

CORRER, Adilson R. A Filosofia na Ratio Studiorum. 2006. 70 páginas.

Dissertação de Mestrado em Educação - Faculdade de Ciências Humanas. Universidade Metodista de Piracicaba. SP. Disponível em: www.unimep.br/phpg/bibdig/aluno. Acessado em 28/07/2011

FONTES, José Silvério Leite. Razão e fé em Jackson de Figueiredo. Aracaju-SE: EDUFS, 1998.

GALLO, Silvio Donizetti de Oliveira. Educaşão anarquista: por uma pedagogia do risco. 1990. Dissertação de Mestrado em Educação. Faculdade de Educação. Universidade Estadual de Campinas. Campinas - SP. . Pedagogia libertária: anarquistas, anarquismos e educação. São Paulo:

Imaginário- Editora da Universidade Federal do Amazonas, 2007. . Deleuze \& a educação. Belo Horizonte: Autêntica, 2003.

GHIRALDELLI JÚNIOR, Paulo. História da educação brasileira. São Paulo: Cortez, 2006 . Filosofia e história da educaşão brasileira: da colônia ao governo Lula. $2^{\mathrm{a}}$ ed.

Barueri, SP: Manole, 2009.

. Filosofia da Educação. $2^{\text {a }}$ ed. Rio de Janeiro: DP\&A, 2002. (O que você precisa saber sobre).

. Neopragmatismo, Escola de Frankfurt e Marxismo. Rio de Janeiro: DP\&A, 2001.

Filosofia e Educação - ISSN 1984-9605 - v. 4, no 1, abril-setembro de 2012 
LAGO, Clenio. Locke e a educação. Chapecó, SC: Argos Editora Universitária, 2002.

MARINHO, Cristiane M. A importância da Missão Francesa para a Filosofia brasileira na fundação da USP. In: Ana Cláudia Giraud [et al] (Orgs.). Ressonâncias: a civilização francesa revisitada. Fortaleza, CE: EdUECE, 2009a. ; ROCHA, Vanda T. S. A filosofia da educação em Rorty através dos textos de Ghiraldelli. Redescrições Revista on-line do GT Pragmatismo e Filosofia Norte-Americana da ANPOF. Ano 1, n. 3. Suplemento: Memória do 1․ Colóquio Internacional Richard Rorty - 2009. Disponível em: www.redescrições.com. Acessado em: 12/12/2011

et al. Filosofia da educação: pressupostos e perspectivas. In: Filosofia da educação. Licenciatura em Pedagogia. Fortaleza: RDS, 2009b.

PAGNI, Pedro Ângelo; CAVALCANTI, Aline. Filosofia da Educação no Brasil (1960-2000): problemas, fontes e conceitos nas práticas do filosofar na educação, s/d. Disponível em www.gepef.pro.br/EGEPEF/.../pedro/aline.pdf. Acessado em 21/10/2011. PAIM, Antônio. O estudo do pensamento filosófico brasileiro. $2^{\mathrm{a}}$ ed. São Paulo: Convívio, 1986. . História das ideias filosóficas no Brasil. $3^{\mathrm{a}}$ ed. São Paulo: Convívio; Brasília: INL, Fundação Nacional Pró-Memória, 1984.

PAIVA, Vanilda. Paulo Freire e o nacionalismo desenvolvimentista. Rio de Janeiro: Civilização, 1980.

PARAÍSO, Marlucy Alves. Pesquisas pós-críticas em educação no Brasil: esboço de um mapa. Cadernos de Pesquisa, v. 34, n. 122, p. 283-303, maio/ago., 2004. Disponível em www.scielo.br/scielo.php?pid=S010015742004000200002...sci.... Acessado em 25/10/2011.

PASSETTI, Edson; AUGUSTO, Acácio. Anarquismos \& Educação. Belo Horizonte: Autêntica Editora, 2008. (Coleção Temas e Educação). SAVIANI, Dermeval. História das idéias pedagógicas no Brasil. Campinas, SP: Autores Associados, 2007. - (Coleção memória da educação).

Filosofia e Educação - ISSN 1984-9605 - v. 4, no 1, abril-setembro de 2012 
SEVERINO, Antônio Joaquim. A filosofia contemporânea no Brasil: conbecimento, política e educação. Petrópolis, RJ: Vozes, 1997.

. A filosofia da educação no Brasil: círculos hermenêuticos. Disponível em: files.professoragiselemasson.webnode.com.br/.../Severino $\% 2$, s/d. Acessado em 18/10/2011.

SILVA, Tomaz Tadeu. Mapeando a [complexa] produção teórica educacional Entrevista com Tomaz Tadeu da Silva. Currículo sem fronteiras, v.2, n.1, pp.514, Jan/Jun., 2002. Disponível em

www.curriculosemfronteiras.org/vol2iss1articles/tomaz.pdf. Acessado em 20/10/2011.

VERNEY, Luís António. Verdadeiro método de estudar. Volume V. Lisboa:

Editora Livraria Sá da Costa, 1952. Coleção de Clássicos Sá da Costa.

Filosofia e Educação - ISSN 1984-9605 - v. 4, no 1, abril-setembro de 2012 